\title{
PENGARUH JUMLAH PENDUDUK MISKIN DAN TINGKAT PENGANGGURAN TERBUKA TERHADAP PERTUMBUHAN EKONOMI DI INDONESIA
}

\author{
Lidyawati Padang ${ }^{* a}$,Murtala ${ }^{* b}$ \\ *Fakultas Ekonomi dan Bisnis Universitas Malikussaleh \\ a Corresponding author:lidyapadang0@gmail.com \\ b murtala@unimal.ac.id
}

A R T I C L E I N F O R M A T I O N

Keywords:

Poor People, Open

Unemployment Rate, Economic

Growth.

\section{A B S T R A C T}

This study aims to determine the effect of the number of poor people and the open unemployment rate on economic growth in Indonesia. This study uses panel data from 2015 to 2019. The method of data analysis used is panel data regression analysis. The results of the study partially show that the number of poor people has a negative and significant effect on economic growth in Indonesia, and the open unemployment rate has a negative and significant effect on economic growth in Indonesia. Simultaneously, the number of poor people and the open unemployment rate have a positive and significant effect on economic growth in Indonesia.

\section{PENDAHULUAN}

Pembangunan yang dilakukan disetiap negara memiliki tujuan yang sama yakni tercapainya kemakmuran dan kesejahteraan masyarakat. Suatu negara akan melakukan berbagai strategi di berbagai bidang baik jangka panjang ataupun jangka pendek untuk mencapai pembangunan ekonomi yang optimal. Bagi suatu negara pembangunan ekonomi sangat penting untuk mengetahui keberhasilan pembangunan yang dicapai. Suatu negara dapat dikatakan mencapai keberhasilan pada pertumbuhan ekonomi dapat dilihat melalui tingkat pertumbuhan ekonominya. Pertumbuhan ekonomi merupakan salah satu indikator yang amat penting dalam suatu perekonomian, (Sukirno, 2015).

Suatu negara dapat dikatakan mencapai keberhasilan pada pertumbuhan ekonomi dapat dilihat melalui tingkat pertumbuhan ekonominya. Pertumbuhan ekonomi merupakan salah satu indikator yang amat penting dalam suatu perekonomian. Pertumbuhan ekonomi dikatakan mengalami pertumbuhan apabila produksi barang dan jasa meningkat dari tahun sebelumnya (Sukirno, 2015). Salah satu faktor yang dapat mempengaruhi keberhasilan pertumbuhan ekonomi adalah jumlah penduduk miskin.
Kemiskinan yang diukur dari jumlah penduduk miskin yang tinggi merupakan masalah utama yang dialami oleh negara berkembang salah satunya Indonesia. Kemiskinan di Indonesia disebabkan berbagai faktor, seperti kondisi investasi, tingkat pengangguran dan lambatnya perekonomian. Dalam upaya meningkatkan kesejahteraan dan menanggulangi kemiskinan, salah satu upaya yang efektif yaitu dengan memperbaiki pertumbuhan ekonomi (Darsana \& AA Gede, 2019).

Kemiskinan memiliki hubungan yang sangat kuat terhadap pertumbuhan ekonomi, jika ekonomi di negara tinggi dapat menurunnya kemiskinan sebaliknya, jika ekonomi wilayah rendah maka kemiskinan akan naik, (Fatmawati \& Khairil, 2018). Selain kemiskinan, pengangguran juga dapat mempengaruhi pertumbuhan ekonomi suatu wilayah. Dalam sudut pandang makroekonomi, pengangguran yang tinggi merupakan suatu masalah. Dampak tingginya tingkat pengangguran akan banyaknya sumber daya sia-sia dan pendapatan masayarakat dapat berkurang. 
Pengangguran terbuka adalah terciptanya pengangguran akibat dari lebih rendanya penambahan lapangan kerja dibandingkan pertumbuhan tenaga kerja. Pengangguran yang tinggi dapat menurunkan tingkat kemakmuran dan kesejahteraan dalam masyarakat. Jika tingkat pengangguran rendah pertumbuhan ekonominya meningkat, begitu juga sebaliknya, Amalia, dalam (I Made \& Putu, 2019).

\section{Tabel 1.1}

Perkembangan JPM, TPT dan

Pertumbuhan Ekonomi Indonesia

Tahun 2014-2018

\begin{tabular}{|c|c|c|c|}
\hline Tahun & $\begin{array}{c}\text { JPM } \\
\text { (Jiwa) }\end{array}$ & $\begin{array}{c}\text { TPT } \\
\text { (\%) }\end{array}$ & $\begin{array}{c}\text { Pertumbuhan } \\
\text { Ekonomi } \\
\text { (Milyar) }\end{array}$ \\
\hline 2015 & 28.513 .570 & 6,18 & 8.982 .517 \\
\hline 2016 & 27.764 .320 & 5,61 & 9.434 .613 \\
\hline 2017 & 26.582 .990 & 5,5 & 9.912 .928 \\
\hline 2018 & 25.674 .580 & 5,34 & 10.425 .397 \\
\hline 2019 & 24.785 .870 & 5,28 & 10.949 .244 \\
\hline
\end{tabular}

Sumber: BPS, 2020

Berdasarkan Publikasi BPS 2020 Tabel 1.1 tahun 2015 sampai 2019 JPM Indonesia berfluktuatif. Pada tahun 2015, ketika JPM meningkat 28.513.570 Jiwa dari tahun sebelumnya 27.727.780 Jiwa, namun disisi pertumbuhan ekonomi Indonesia tahun 2015 juga meningkat Rp. 8.982.517 Milyar dari tahun sebelum Rp. 8.564.867 Milyar. Hal tersebut tidak sejalan dengan teori menurut Kuznet, dalam (Fatmawati \& Khairil, 2018), yang menyimpulkan bahwa pertumbuhan dan kemiskinan memiliki hubungan yang sangat kuat dan saling berhubungan satu sama lain, karena pada tahap awal sebuah proses pembangunan tingkat kemiskinan cenderung naik kemudian pada saat mendekati tahap akhir dari pembangunan jumlah penduduk miskin perlahan-lahan akan berkurang dengan arti lain jika tingkat kemiskinan daerah tinggi maka akan melambatkan ekonominya.

Teori tersebut didukung hasil penelitian (Novriansyah, 2018) kemiskinan mempengaruhi pertumbuhan ekonomi di Provinsi Gorontalo.

Selanjutnya, TPT berdasarkan BPS Tabel 1.1 berfluktuatif. Pada tahun 2015, ketika TPT meningkat $6,18 \%$ dari tahun sebelumnya 5,94\%, namun disisi pertumbuhan ekonomi juga meningkat Rp.8.982.517 Milyar dari tahun sebelumnya Rp.8.564.867 Milyar. Teori Hukum Okun (Okun's
Law) bahwa adanya hubungan erat pengangguran dengan GNP Rill. Dalam hukum tersebut disebutkan bahwa tingginya laju pertumbuhan pertumbuhan dapat menurunnya tingkat pengangguran, dan rendahnya laju pertumbuhan akan meningkatkan pengangguran, (Hasyim, 2016). Teori Hukum Okun's Law sejalan dengan penelitian (Novriansyah, 2018) pengangguran berpengaruh secara positif terhadap pertumbuhan ekonomi di Gorontalo.

Penelitian sebelumnya (Novriansyah, 2018) telah mengkaji tentang pengaruh kemiskinan dan pengangguran terhadap pertumbuhan ekonomi. Dalam penelitian ini berbeda dengan penelitian sebelumnya, penelitian sebelumnya menggunakan OLS, sedangkan penulis memaai analisis regresi data panel. Kemudian perbedaan lainnya terdapat pada ruang lingkup penelitian, penelitian sebelumnya berada di Gorontalo sementara penelitian ini ruang lingkupnya di 34 Provinsi Indonesia

\section{KAJIAN TEORITIS Pertumbuhan Ekonomi}

Pertumbuhan ekonomi ialah proses perubahan kondisi suatu ekonomi negara secara berkesinambungan menuju arah yang baik selama waktu tertentu (Putra, 2018). Pertumbuhan ekonomi diartikan sebagai proses kondisi ekonomi wilayah berubah pada waktu tertentu (Hasyim, 2016). Sedangkan dalam (Sukirno, 2015) Pertumbuhan ekonomi sebagai perkembangan kegiatan perekonomian yang berakibat meningkatnya produksi di daerah.

\section{Jumlah Penduduk Miskin}

Penduduk miskin sebagai anggota rumah tangga miskin, rumah tangga miskin adalah rumah tangga dengan rata-rata pengeluaran per kapita per bulan kurang dari garis kemiskinan (BPS, 2020). Kemiskinan sebagai tidak mampunya seorang maupun sekelompok mencukupi kebutuhan standar hidupnya (Machmud, 2016). (Humbarsari, 2016) Kemiskinan sebagai tidakmampunya orang memperoleh pendapatan mencukupi kebutuhankebutuhan dasarnya.

\section{Tingkat Pengangguran Terbuka}


Pengangguran terbuka adalah persentasi penduduk yang tidak mempunyai pekerjaan Kussetiyono dalam (Safrina, 2018). (Subri, 2014), pengangguran terbuka yaitu angkatan kerja sekarang ini tidak bekerja dan sedang aktif mencari pekerjaan. Pengangguran ialah orang tergolong angkatan kerja, ingin mendapatkan pekerjaan tetapi belum memperoleh pekerjaan, (Sukirno, 2015).

\section{KerangkaKonseptual}

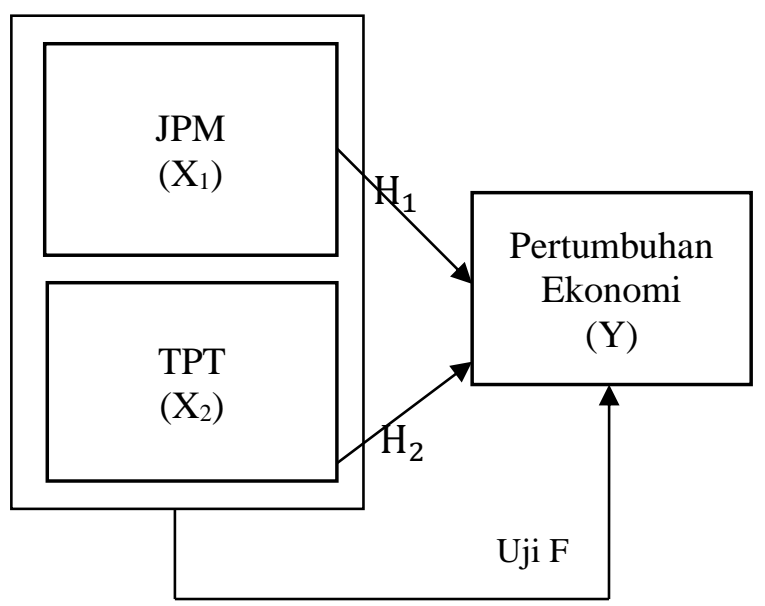

Gambar 1. Kerangka Konseptual

Kerangka konseptual pada gambar 1 menjelaskan pengaruh JPM $\left(\mathrm{X}_{1}\right)$ dan TPT $\left(\mathrm{X}_{2}\right)$ terhadap pertumbuhan ekonomi $(\mathrm{Y})$ di uji dengan uji t, dan dengan uji $F$.

\section{Hipotesis Penelitian}

Berikut hipotesis penelitian:

$\mathrm{H}_{1}$ : Diduga JPM berpengaruh terhadap pertumbuhan ekonomi di Indonesia.

$\mathrm{H}_{2}$ : Diduga TPT berpengaruh terhadap pertumbuhan ekonomi di Indonesia.

\section{METODE PENELITIAN Teknik Pengumpulan Data}

Jenis penelitian adalah penelitian kuantitatif, data sekunder bentuk data panel yaitu gabungan data time series dan cross section. Time series selama 5 tahun (2015-2019) dan cross section 34 provinsi Indonesia sehingga jumlah observasi sebanyak 170 observasi.

Teknik pengumpulan data dalam penelitian ini adalah dokumentasi. Dokumentasi merupakan data bersumber dari literatur kepustakaan, laporan penelitian sebelumnya atau catatan yang mendukung penelitian iniseperti sumber buku, internet dan literatur lainnya.

\section{Definisi Operasional Variabel}

Operasionalisasi variabel merupakan petunjuk bagaimana variabel-variabel dalam penelitian diukur.

1. Pertumbuhan Ekonomi (Y)

Pertumbuhan ekonomi periode 2014-2018

diunduh dari BPS diukur dalam satuan miliar rupiah.

2. $\mathrm{JPM}(\mathrm{X} 1)$

JPM periode 2014-2018 di unduh dari BPS diukur dengan satuan ribu jiwa.

3. TPT (X2)

TPT periode 2014-2018 diunduh dari BPS diukur dengan satuan persen.

\section{Metode Analisis Data}

Metode analisis adalah analisis regresi data panel dengan program E-Views 10. Berikut modelnya:

$$
\text { LOGY }=\alpha+\beta_{1} \text { LOGX1 }_{1 \mathrm{it}}+\beta_{2} \mathrm{LOGX}_{2 \mathrm{it}}+e
$$

Dimana:

Y : Pertumbuhan Ekonomi

$\alpha \quad$ : Konstanta

$\mathrm{X} 1: \mathrm{JPM}$

$\mathrm{X} 2$ : TPT

e : Error Term

$i \quad$ : Banyaknya Observasi

$t$ : Banyaknya Waktu

\section{Model Regresi Data Panel:}

\section{a. Common Effect Model}

Dalam model ini mengabaikan dimensi waktu dan ruang karena intercept dan koefesien slope dianggap konstan. Berikut persamaan regresinya (Gujarati, 2012):

$$
Y_{i t}=\alpha+\beta_{1} X_{1 i t}+\beta_{2} X_{2 i t}+\beta_{3} X_{3 i t}+\mu_{i i t}
$$

Dimana :

i : Unit Cross-sectiont (individual)

$\mathrm{t}$ : Periode Waktu

\section{b. Fixced Effect Model}

Dalam model ini ada perbedaan intercept antara individu, tetapi intercept watu, koefisien dan slope individu atau waktu adalah sama. Berikut persamaannya (Gujarati, 2012):

$$
Y_{i t}=\alpha+\beta_{1} X_{i t}+\beta_{2} X_{2 i t}+\beta_{3} W_{i t}+D_{3} Z_{1 i t}+\text { eit }
$$

Dimana:

Wit $=1$ untuk daerah ke $\mathrm{i}$ 
Zit $=1$ untuk periode $\mathrm{ke} \mathrm{t}$

\section{c. Random Effect Model}

Dalam model in slope antar individu sama, tetapi intercep berbeda. Berikut persamaan regresinya (Gujarati, 2012):

$$
Y_{i t}=\alpha+\beta_{1} X_{1 i t}+\beta_{2} X_{2 i t}+\beta_{3} X_{3 i t}+\text { eit }+\mu_{\text {iit }}
$$

\section{Model Estimasi Regresi Data Panel}

\section{a) Uji Chow}

Uji chow menguji common effect dengan fixced effect (Widarjono, 2017). Hipotesis uji chow:

$$
\begin{aligned}
& \mathrm{H}_{0} \text { : common effect } \\
& \mathrm{H}_{1} \text { : fixced effect }
\end{aligned}
$$

$\mathrm{H}_{0}$ ditolak jika probabilitas cross-section Chi-square $<0,05$. Sebaliknya, $\mathrm{H}_{0}$ diterima jika probabilitas cross-section Chi-square $>0,05$.

\section{b) Uji Hausman}

Uji Hausman membandingkan fixced effect dengan random effect (Widarjono, 2017). Hipotesis uji hausman:

$$
\begin{aligned}
& \mathrm{H}_{0} \text { : random effect } \\
& \mathrm{H}_{1} \text { : fixced effect }
\end{aligned}
$$

$\mathrm{H}_{0}$ ditolak jika probabilitas cross-section < 0,05 . Sebaliknya, $\mathrm{H}_{0}$ diterima jika probabilitas cross-section $>0,05$.

\section{Uji Asumsi Klasik}

\section{1) Uji Multikolinieritas}

Uji multikolinieritas merupakan kondisi adanya korelasi atau hubungan antara variabel independen dilihat melalui nilai korelasinya. Jika nilai korelasinya di bawah 0,80 maka terbebas multikolinieritas (Widarjono, 2017).

\section{2) Uji Heteroskedastisitas}

Uji heteroskadastisitas merupakan adanya ketidaksamaan variance dari residual satu pengamatan terhadap pengamatan lain dilihat nilai probabilitas Obs*R-Squared. Jika nilai probabilitas Obs*R-Squared diatas 0,05, maka tidak ada heteroskedastisitas (Widarjono, 2017).

\section{Pengujian Statistik}

Uji t-Statistik
Uji parsial untuk melihat besarnya pengaruh variabel bebas terhadap variabel terikat (Ghozali, 2006). Kriteria pengujiannya:

1. jika $t_{\text {hitung }}>t_{\text {tabel }}$ dengan tingkat signifikan $5 \%$ atau 0,05 , secara parsial variabel bebas berpengaruh terhadap variabel terikat.

2. jika $t_{\text {hitung }}<t_{\text {tabel }}$ dengan tingkat signifikan $5 \%$ atau 0,05 , secara parsial variabel bebas tidak berpengaruh terhadap variabel terikatnya.

\section{Uji F-statistik}

Uji F melihat pengaruh variabel bebas secara bersama terhadap variabel terikat (Ghozali, 2006). Kriteria pengujiannya:

1. Jika $F_{\text {hitung }}>F_{\text {tabel }}$ dengan ketentuan tingkat signifikan $5 \%$ atau 0,05 , secara serentak variabel bebas memiliki pengaruh signifikan terhadap variabel terikat.

2. Jika $F_{\text {hitung }}<F_{\text {tabel }}$ dengan ketentuan tingkat signifikan $5 \%$ atau 0,05 , secara serentak variabel bebas tidak berpengaruh terhadap variabel terikat.

\section{Koefisien Determinasi $\left(\mathbf{R}^{\mathbf{2}}\right)$}

Pengujian koefisien determinasi melihat besarnya pengaruh variabel bebas terhadap perubahan variabel terikat. Dalam (Gujarati, 2012), nilai koefisien determinasi sebesar 0 dan 1 . Jika ${ }^{2}$ mendekati 1 semakin kuat pengaruhnya dan jika ${ }^{2}$ mendekati 0 semakin kecil pengaruhnya.

\section{HASIL PENELITIAN DAN PEMBAHASAN}

\section{Hasil Penelitian}

\section{Hasil Uji Asumsi Klasik}

\section{1) Hasil Uji Multikolinieritas}

Melihat adakah hubungan antara variabel independenya dilakukan uji multikolinieritas melalui nilai korelasi. Berikut hasilnya:

Tabel 1

Hasil Pengujian Multikolinieritas

\begin{tabular}{|c|c|c|}
\hline & LOGX1 & LOGX2 \\
\hline LOGX1 & 1.000000 & 0.094167 \\
\hline LOGX2 & 0.094167 & 1.000000 \\
\hline
\end{tabular}

Sumber: Hasil Olah Data, 2020

Berdasarkan Tabel 1 variabel LOGX1 dan variabel LOGX2 tidak adanya hubungan korelasi 
karena nilai korelasinya berada dibawah 0.80 , maka terbebas multikolinieritas.

\section{2) Hasil Uji Heteroskedastisitas}

Pengujiannya dilalukan guna mengetahui adanya gangguan dilakukan uji heteroskedasisitas dilihat melalui probabilitas chi-square pada Obs*Rsquared. Berikut hasilnya:

Tabel 2

Hasil Pengujian Heteroskedastisitas

\begin{tabular}{|l|l|l|l|}
\hline \multicolumn{4}{|c|}{ Uji Heteroskedastisitas: Glesjer } \\
\hline F-Statistik & 2.174330 & Prob.F(2,167) & 0.1169 \\
\hline $\begin{array}{l}\text { Obs*R- } \\
\text { squared }\end{array}$ & 4.314432 & $\begin{array}{l}\text { Prob.Chi- } \\
\text { Square(2) }\end{array}$ & 0.1156 \\
\hline $\begin{array}{l}\text { Scaled } \\
\text { explained SS }\end{array}$ & 4.668126 & $\begin{array}{l}\text { Prob.Chi- } \\
\text { Square(2) }\end{array}$ & 0.0969 \\
\hline
\end{tabular}

Sumber: Hasil Olah Data, 2020

Berdasarkan pada Tabel 2 probabilitas dari chi-square $>$ alpha $5 \%$ yaitu $(0.1156>0,05)$. Maka terbebas heteroskedastisitas

\section{Hasil Model Estimasi Regresi Data Panel}

\section{1) Hasil Uji Chow}

Uji chow dilakukan untuk menguji common effect dengan fixced effect dilihat melalui nilai probabilitas Cross-section Chi-Square. Hasilnya berikut ini.

\section{Tabel 3}

Hasil Uji Chow

\begin{tabular}{|l|c|c|c|}
\hline \multicolumn{4}{|c|}{ Test cross-section Fixced Effects } \\
\hline Effects Test & Statistik & d.f. & Prob \\
\hline Cross-section F & 709.292672 & $(33,134)$ & 0.0000 \\
\hline $\begin{array}{l}\text { Cross-section } \\
\text { Chi-square }\end{array}$ & 878.669527 & 33 & 0.0000 \\
\hline
\end{tabular}

Sumber: Hasil Olah Data, 2020

Dari Tabel 3 nilai probabilitas Chi-Square sebesar $(0,0001<0,05)$, regresi fixced effect lebih baik dari common effect.

\section{2) Hasil Uji Hausman}

Menguji fixced effect dan random effect melalui nilai probabilitas Cross-section random. Hasilnya:
Test Cross-Section Random Effects

\begin{tabular}{|l|c|c|c|}
\hline Test Summary & $\begin{array}{l}\text { Chi- } \\
\text { Sq.Statistic }\end{array}$ & $\begin{array}{l}\text { Chi - } \\
\text { Sq.d.f }\end{array}$ & Prob \\
\hline $\begin{array}{l}\text { Cross-Section } \\
\text { Random }\end{array}$ & 68.023915 & 2 & 0.0000 \\
\hline
\end{tabular}

Sumber: Hasil Olah Data, 2020

Berdasarkan Tabel 4 nilai probabilitas cross-section random $(0.0000<0.05)$ maka fixced effect lebih baik dari random effect

\section{Analisis Regresi Data Panel}

Model yang terpilih fixced effect. Berikut hasil hasilnya:

Tabel 5

Hasil Uji Fixced Effect Model

\begin{tabular}{|c|c|c|c|c|}
\hline Variabel & Koefisien & $\begin{array}{c}\text { Std. } \\
\text { Error }\end{array}$ & t-Hitung & Prob \\
\hline C & 20.1424 & 1.3643 & 14.7638 & 0.0000 \\
\hline LOG(X1) & -0.6236 & 0.1063 & -5.8642 & 0.0000 \\
\hline LOG(X2) & -0.1264 & 0.0346 & -3.6585 & 0.0004 \\
\hline
\end{tabular}

Sumber: Hasil Olah Data, 2020

Berdasarkan Tabel 5 diperoleh persamaan: $\mathrm{Y}=20.1424-0.6236$ LOGX1 - 0.1264LOGX2

Berikut penjelasan persamaannya:

1. Nilai koefisien konstanta sebesar 20.1424, ini berarti apabila JPM dan TPT dianggap konstan, maka pertumbuhan ekonomi konstan $20.1424 \%$.

2. Nilai koefisien JPM (X1) sebesar 0.6236, ini berarti apabila terjadi peningkatan JPM sebesar $1 \%$ maka akan menurunkan pertumbuhan ekonomi sebesar $0.6236 \%$.

3. Nilai koefisien TPT (X2) sebesar 0.1264, ini berarti apabila terjadi peningkatan TPT sebesar $1 \%$ maka akan menurunkan pertumbuhan ekonomi sebesar $0.1264 \%$.

Hasil Uji t-Statistik

Berikut hasil pengujian parsial:

Tabel 6

Hasil Pengujian Parsial (Uji t)

\begin{tabular}{|c|c|c|c|}
\hline $\begin{array}{c}\text { Variabel } \\
\text { Bebas }\end{array}$ & t-Statistik & t-Tabel & Prob \\
\hline JPM & -5.8642 & 1.6540 & 0.0000 \\
\hline TPT & -3.6585 & 1.6540 & 0.0004 \\
\hline
\end{tabular}

Sumber: Hasil Olah Data, 2020

Berdasarkan Tabel 6:
Tabel 4 Hasil Uji Hausman 
1. variabel JPM (X1) memiliki nilai $t_{\text {hitung }}=-$ $5.8642>\mathrm{t}_{\text {tabel }}-1.6540$ diperoleh $\alpha 0.05, \mathrm{H}_{1}$ diterima dan tolak $\mathrm{H}_{0}$ artinya JPM berpengaruh negatif dan signifikan terhadap pertumbuhan ekonomi Indonesia.

2. variabel TPT memiliki nilai $t_{\text {hitung }}=-3.6585$ $>t_{\text {tabel }}-1.6540$, diperoleh $\alpha 0.05, \mathrm{H}_{2}$ diterima dan tolak $\mathrm{H}_{0}$ artinya bahwa TPT berpengaruh negatif dan signifikan terhadap pertumbuhan ekonomi di Indonesia.

\section{Hasil Uji F-Statistik}

Berikut hasil pengujian simultan:

Tabel 7

Hasil Pengujian Simultan (Uji F)

\begin{tabular}{|c|c|c|}
\hline F-Statistik & F- Tabel & Probabilitas \\
\hline 1323.79 & 3.05 & 0.000000 \\
\hline
\end{tabular}

Sumber: Hasil Olah Data, 2020

Berdasarkan Tabel 7 nilai dari $\mathrm{F}_{\text {hitung }}=$ 1323.786 nilai $F_{\text {tabel }}$ sebesar 3.05 dari $\alpha 0,05$. Jadi $\mathrm{F}_{\text {hitung }} 1323.786>\mathrm{F}_{\text {tabel }}$ 3.05,secara bersamasama dengan tingkat kepercayaan 95\% JPM dan TPT berpengaruh positif dan signifikan terhadap pertumbuhan ekonomi di Indonesia. dan probabilitasnya signifikan $0.000000<0.05$.

\section{Hasil Pengujian Koefisien Determinasi $\left(\mathbf{R}^{2}\right)$}

Berikut hasil $\mathrm{R}^{2}$ dilihat melalui nilai Adjusted R-Squared:

\section{Tabel 8}

Hasil Pengujian Koefisien Determinasi $\left(\mathbf{R}^{2}\right)$

\begin{tabular}{|c|c|}
\hline Variabel & Koefisien \\
\hline Adjusted R-Squared & 0.996363 \\
\hline
\end{tabular}

Sumber: Hasil Olah Data, 2020

Berdasarkan Tabel 8, nilai Adjusted RSquared 0.996363, artinya hubungan antara JPM dan TPT terhadap pertumbuhan ekonomi sangat kuat sebesar 99,64\% sedangkan 00,36\% lainnya dipengaruhi oleh variabel di luar penelitian ini.
Hasil Setiap Provinsi Berdasarkan Fixced Effect Terpilih

Tabel. 9

Taksiran Parameter FEM

\begin{tabular}{|l|c|c|}
\hline \multicolumn{1}{|c|}{ Provinsi } & Koefisien & Intersep \\
\hline Aceh & 0.317949 & 19.824441 \\
\hline Sumut & 1.986086 & 18.156304 \\
\hline Sumbar & -0.005350 & 20.14774 \\
\hline Riau & 1.351991 & 18.790399 \\
\hline Jambi & -0.304788 & 20.447178 \\
\hline Sumsel & 1.270612 & 18.871778 \\
\hline Bengkulu & -1.444260 & 21.58665 \\
\hline Lampung & 1.023716 & 19.118674 \\
\hline Kep.Babel & -2.196862 & 22.339252 \\
\hline Kep.Riau & -0.558211 & 20.700601 \\
\hline DKI. Jakarta & 2.408293 & 17.734151 \\
\hline Jabar & 3.692597 & 16.449793 \\
\hline Jateng & 3.255188 & 16.887202 \\
\hline DI & -0.418349 & 20.560739 \\
Yogyakarta & & \\
\hline Jatim & 3.786130 & 16.35626 \\
\hline Banten & 1.403634 & 18.738756 \\
\hline Bali & -0.656417 & 20.798807 \\
\hline NTB & -0.094157 & 20.236547 \\
\hline NTT & -0.245994 & 20.388384 \\
\hline Kalbar & -0.204026 & 20.346416 \\
\hline Kalteng & -1.178610 & 21.321 \\
\hline Kalsel & -0.654180 & 20.79657 \\
\hline Kaltim & 0.802697 & 19.339693 \\
\hline Kalut & -2.317865 & 22.460255 \\
\hline Sulut & -1.021489 & 21.163879 \\
\hline Sulteng & -0.416065 & 20.558455 \\
\hline Sulsel & 1.106692 & 19.035698 \\
\hline Sulgara & -0.750978 & 20.893368 \\
\hline Gorontalo & -2.247901 & 22.390291 \\
\hline Sulbar & -2.247808 & 22.390198 \\
\hline Maluku & -1.748591 & 21.890981 \\
\hline Malut & -2.847336 & 22.989726 \\
\hline P. Barat & -1.298479 & 21.440869 \\
\hline Papua & 0.452130 & 19.69026 \\
Suber: Hail 01 Data \\
\hline
\end{tabular}

Sumber: Hasil Olah Data, 2020

Berdasarkan hasil perhitungan Tabel 9, intersep tertinggi di Maluku Utara sebesar 22.989726, Kalimantan Utara sebesar 22.460255, Gorontalo sebesar 22.390291, Sulawesi Barat sebesar 22.390198, Kepulauan Bangka Belitung sebesar 22.339252 .

Kemudian, intersep terkecil di Jawa Timur sebesar 16.35626, Jawa Barat sebesar 16.449793, Jawa Tengah sebesar 16.887202 dan DKI Jakarta sebesar 17.734151. 
Dari hasil Tabel 9, dijelaskan nilai intersep dua provinsi berdasarkan nilai tertinggi (Maluku Utara) dan terendah (Jawa Timur):

\section{Maluku Utara}

Maluku Utara memiliki intersep tertinggi sebesar 22.989726, artinya apabila JPM dan TPT di Maluku Utara dianggap konstan maka pertumbuhan ekonomi Maluku Utara juga konstan sebesar 22.99\%.

\section{Jawa Timur}

Jawa Timur memiliki intersep terkecil sebesar 16.35626, artinya apabila JPM dan TPT di Jawa Timur dianggap konstan maka pertumbuhan ekonomi di Jawa Timur juga konstan sebesar 16.36\%.

\section{Pembahasan}

fixced effect merupakan model regresi yang terpilih. Berikut penjelasannya

\section{Pengaruh JPM Terhadap Pertumbuhan Ekonomi Di Indonesia.}

JPM terhadap pertumbuhan ekonomi berpengaruh negatif dan signifikan. Artinya apabila JPM meningkat $1 \%$, pertumbuhan ekonominya menurun sebesar $1 \%$. Hal ini berarti kemiskinan yang diukur dari JPM tinggi maka dapat menghambat keberhasilan pertumbuhan ekonominya. Hasil penelitian sejalan dengan (Parmadi \& Selamet, 2019), kemiskinan yang diukur dari jumlah penduduk miskin berpengaruh negatif terhadap pertumbuhan ekonomi antar Pulau di Indonesia.

\section{Pengaruh TPT Terhadap Pertumbuhan Ekonomi Di Indonesia.}

TPT terhadap pertumbuhan ekonomi berpengaruh negatif dan signifikan. Artinya apabila TPT meningkat sebesar $1 \%$ maka pertumbuhan ekonominya menurun sebesar $1 \%$. Hal ini berarti pengangguran diukur dari TPT tinggi dapat melambatkan perekonominya. Hasil penelitian sejalan dengan (Masruroh, 2020), TPT bepengaruh secara negatif dan signifikan terhadap pertumbuhan ekonomi di Jawa Timur.

\section{KESIMPULAN DAN SARAN Kesimpulan}

Berdasarkan hasil analisis dapat diberi kesimpulan:

1. Variabel JPM secara parsial berpengaruh secara negatif dan signifikan terhadap pertumbuhan ekonomi di Indonesia

2. Variabel TPT secara parsial berpengaruh secara negatif dan signifiksn terhadap pertumbuhan ekonomi di Indonesia.

\section{Saran}

Berdasarkan dari hasil analisis dapat memberikan beberapa saran:

1. Disarankan kepada pemerintah hendaknya menekan serendah mungkin kemiskinan dengan melakukan pembangunan secara merata disegala aspek. Pelaksanaan pembangunan hendaknya diarahkan pada terciptanya lapangan kerja secara luas bagi masyarakat, baik dipedesaan maupun diperkotaan sehingga pengangguran dapat berkurang.

2. Kepada peneliti yang tertarik pada variabel ini disarankan untuk mengambil rentan waktu yang lebih lama dan menambahkan variabel-variabel lainnya, supaya dapat memberikan hasil lebih relevan terhadap pertumbuhan ekonomi Indonesia.

3. Diharapkan penelitian ini dapat memberikan ilmu pemahaman kepada masyarakat tentang permasalahan di Indonesia khususnya jumlah penduduk miskin, dan tingkat pengaangguran terbuka terhadap pertumbuhan ekonomi Indonesia.

\section{DAFTAR PUSTAKA}

BPS. (2020). Penduduk Miskin.

Darsana, I. B., \& AA Gede, K. P. (2019). Pengaruh Kemiskinan Dan Investasi Terhadap Pertumbuhan Ekonomi Dan Kesejahteraan Masyarakat. E-Jurnal EP Unud, 8(6), 13001330.

Fatmawati, \& Khairil, A. (2018). Pengaruh Jumlah Penduduk Usia Produktif, Kemiskinan dan Inflasi Terhadap Pertumbuhan Ekonomi di Kabupaten Bireuen. Jurnal Ekonomi Regional Unimal, 1(1), 15-22.

Ghozali, I. (2006). Aplikasi analisis Multivariate dengan Program SPSS (4th ed.). Universitas Diponegoro. 
Gujarati, N. . (2012). Dasar-Dasar Ekonometriks (7th ed.). Salemba Empat.

Hasyim. (2016). Ekonomi Makro. Prenadamedia group.

Humbarsari. (2016). Analisis Pengaruh Pertumbuhan Ekonomi, Pertumbuhan Penduduk, dan Inflasi Terhadap Tingkat Kemiskinan di Jawa Timur Tahun 2004-2014. Jurnal Ekonomi Dan Bisnis, 1(2).

I Made, J., \& Putu, B. K. A. D. (2019). Pengaruh investasi dan pengangguran terhadap pertumbuhan ekonomi dan kemiskinan di provinsi bali. E-Jurnal EP Unud, 8(9), 20722101.

Machmud, A. (2016). Perekonomian Indonesia Pasca Reformasi. Erlangga.

Masruroh. (2020). Pengaruh Tingkat Pengangguran Terbuka Terhadap Pertumbuhan Ekonomi di Jawa Timur.

Novriansyah, M. A. (2018). Pengaruh Pengangguran dan Kemiskinan Terhadap Pertumbuhan Ekonomi di Provinsi Gorontalo. Gorontalo Development Review, 1(1), 59-73.

Parmadi, \& Selamet, R. (2019). Pengaruh ketimpangan pendapatan dan kemiskinan terhadap pertumbuhan ekonomi antar pulau di Indonesia. Paradigma Ekonomika, 14(3), 5566.

Putra, W. (2018). Perekonomian Indonesia. Penerapan Beberapa Teori Ekonomi Pembangunan di Indonesia. PT Rajagrafindo Persada.

Safrina. (2018). Pengaruh Pertumbuhan Ekonomi, Upah Minimum dan Tingkat Pengangguran Terbuka Terhadap Kemiskinan di Kabupaten Aceh Utara. Universitas Malikussaleh.

Subri, M. (2014). Ekonomi Sumber Daya Manusia Dalam Prespektif Pembangunan (Edisi Revi). PT Rajagrafindo Persada.

Sukirno, S. (2015). Makroekonomi Teori Pengantar (Edisi Keti). PT Rajagrafindo Persada.

Widarjono, A. (2017). Ekonometrika (Edisis 4). UPP STIM YKPN. 